\title{
The Expanding Role of MT1-MMP in Cancer Progression
}

\author{
Anna M. Knapinska ${ }^{1}$ and Gregg B. Fields ${ }^{1,2, *(0)}$ \\ 1 Department of Chemistry \& Biochemistry and the Center for Molecular Biology \& Biotechnology, \\ Florida Atlantic University, Jupiter, FL 33458 USA; ania.knapinska@fau.edu \\ 2 Department of Chemistry, The Scripps Research Institute/Scripps Florida, Jupiter, FL 33458, USA \\ * Correspondence: fieldsg@fau.edu; Tel.: +1-561-799-8577
}

Received: 1 May 2019; Accepted: 18 May 2019; Published: 20 May 2019

\begin{abstract}
For over 20 years, membrane type 1 matrix metalloproteinase (MT1-MMP) has been recognized as a key component in cancer progression. Initially, the primary roles assigned to MT1-MMP were the activation of proMMP-2 and degradation of fibrillar collagen. Proteomics has revealed a great array of MT1-MMP substrates, and MT1-MMP selective inhibitors have allowed for a more complete mapping of MT1-MMP biological functions. MT1-MMP has extensive sheddase activities, is both a positive and negative regulator of angiogenesis, can act intracellularly and as a transcription factor, and modulates immune responses. We presently examine the multi-faceted role of MT1-MMP in cancer, with a consideration of how the diversity of MT1-MMP behaviors impacts the application of MT1-MMP inhibitors.
\end{abstract}

Keywords: matrix metalloproteinase; extracellular matrix; cancer progression; immunosuppression; signal transduction; collagenolysis

\section{Introduction}

Membrane type 1 matrix metalloproteinase (MT1-MMP) was initially identified as a cell surface protease present in tumor cells [1]. Since then, MT1-MMP has become a highly sought after target in cancer therapy. The expression of MT1-MMP has been associated with poor prognosis in patients with melanoma, pancreatic cancer, advanced neuroblastoma, small cell and non-small cell lung cancer, mesothelioma, tongue squamous cell carcinoma, head and neck carcinoma, bladder cancer, breast cancer, colorectal cancer, and ovarian cancer [2-5]. Increased tumor cell expression of MT1-MMP enhances metastasis [6,7]. MT1-MMP induces the epithelial to mesenchymal transition (EMT) in prostate and squamous cell carcinoma cells [8,9]. MT1-MMP is needed for tumor cell transmigration through endothelium and basement membrane invasion [10]. Gliomas induce MT1-MMP expression and activity in microglial cells [11]. Cancer stems cells/tumor-initiating cells require MT1-MMP for growth, tumor initiation, invasion and metastasis, particularly in hypoxic, nutrient-deprived environments [12]. MT1-MMP is generally considered pro-invasive and pro-tumorigenic as (a) the expression and activity of MT1-MMP are elevated in tumor tissues and (b) high levels of MT1-MMP directly correlate with enhanced cell migration and tumor regional invasion/remote metastasis $[13,14]$.

While extensive data indicates a significant role for MT1-MMP in cancer, studies of MT1-MMP have often focused on its activation of proMMP-2, hydrolysis of collagen, and shedding of CD44. Mass spectrometric analysis of biotin-labeled cell surface proteins revealed 158 binding partners for MT1-MMP [7]. MT1-MMP cell surface binding partners that have been validated include tetraspanins (CD9, CD37, CD53, CD63, CD81, CD82, CD151, and/or TSPAN12), the $\alpha 2 \beta 1$ and $\alpha v \beta 3$ integrins, CD44, and a ternary complex with tetraspanins and the $\alpha 3 \beta 1$ integrin [7,15-20]. Proteomic approaches have uncovered a vast array of potential MT1-MMP substrates [21-25]. Advancements in bioanalytical 
methods have revealed that the precise behaviors of MT1-MMP that contribute to disease initiation and progression are now greater than believed even a few years ago [26-28].

\section{Activities of MT1-MMP}

MT1-MMP functions on multiple levels in cancer growth and invasion (Figure 1). MT1-MMP can act in the following ways: (a) proteolysis of extracellular matrix (ECM) biomolecules, such as collagen, which allows for the activation of cell signaling pathways (based on the fragments generated by MT1-MMP action) and cell invasion through the ECM; (b) binding of ligands to MT1-MMP, which causes structural changes in MT1-MMP that affects interactions of MT1-MMP to cell surface partners and intracellular signaling of MT1-MMP via the cytoplasmic tail (CT); (c) intracellular proteolysis; and (d) as a transcription factor.

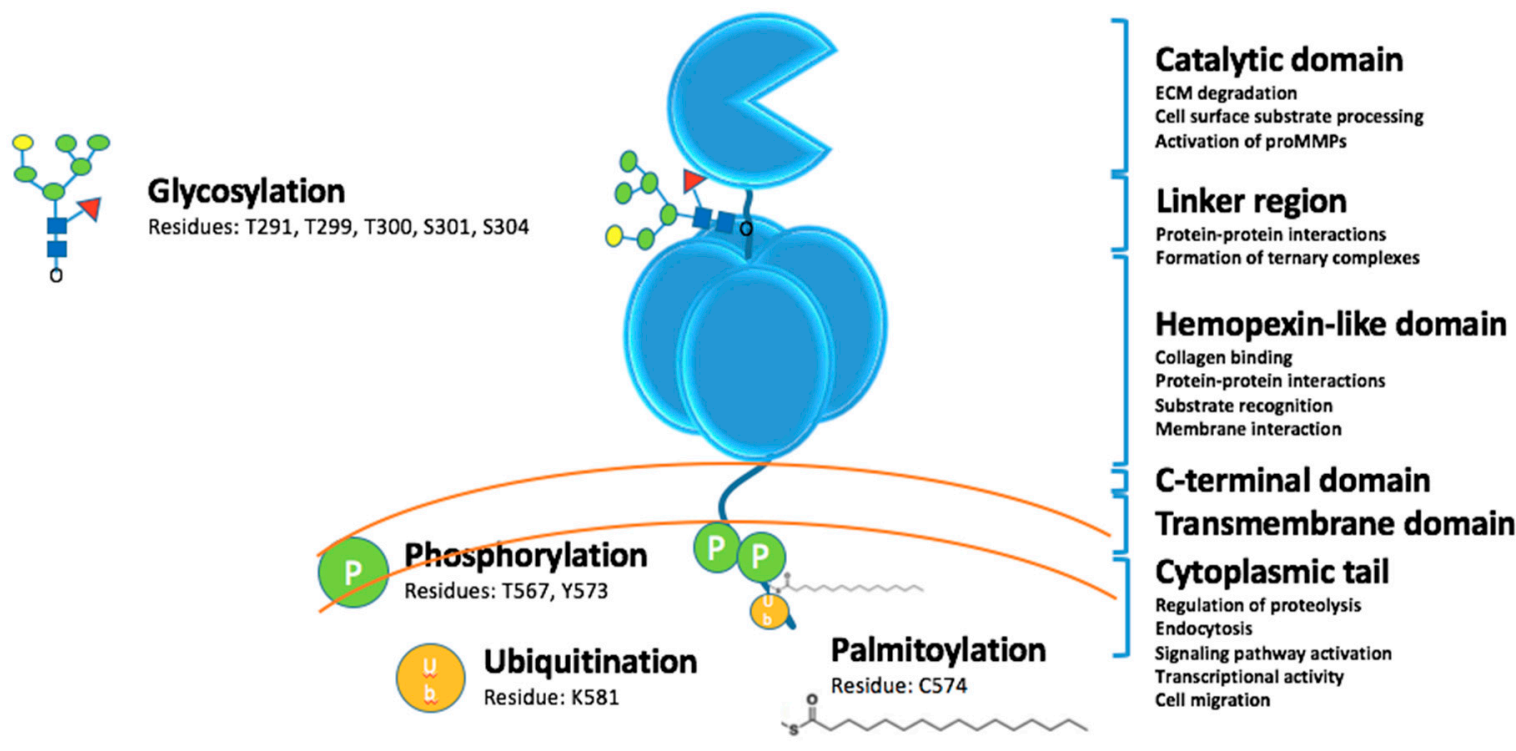

Figure 1. MT1-MMP domains and posttranslational modifications.

\subsection{Extracellular Catalytic Activities}

MT1-MMP was initially recognized for activating proMMP-2 [1,29-33]. MT1-MMP was subsequently shown to process types I, II, and III collagen and gelatin [33-35]. The combined action of MT1-MMP and MMP-2 was proposed to enhance ECM degradation and subsequent invasion [36,37]. Phagocytosis of collagen was found to be mediated by MT1-MMP, where the additional action of MMP-2 was not required [38,39]. MT1-MMP is the dominant collagenase for tumor invasion [40,41] and the proteolytic activity of MT1-MMP is critical for tumor cell invasion of three-dimensional (3D) collagen matrices [42-46]. Similarly, MT1-MMP promoted neovessel formation by facilitating endothelial cell invasion of collagenous matrices and tubulogenesis [47,48]. MT1-MMP is localized in invadopodia for ECM degradation and cell invasion [49,50].

In addition to proMMP-2, MT1-MMP can activate proMMP-13 [51]. In contrast, MT1-MMP processing of active MMP-11 inactivates the enzyme [52]. MT1-MMP has been shown to cleave and activate Notch1, leading to melanoma growth [53]. MT1-MMP activates the pro- $\alpha \mathrm{V}$ integrin subunit, stimulating focal adhesion kinase (FAK) phosphorylation and cell migration on vitronectin [54]. MT1-MMP activates latent transforming growth factor- $\beta$ (TGF- $\beta$ ) $[55,56]$ and can release TGF- $\beta$ by proteolytically processing the latent TGF- $\beta$ binding protein (LTBP-1) [57]. MT1-MMP activation of TGF- $\beta$ signaling induces the upregulation of CUTL1 and Wnt5a and ultimately EMT in prostate cancer cells [56]. MT1-MMP induction of EMT in squamous cell carcinoma was associated with increased levels of Twist, ZEB1, and ZEB2 and the repressed transcription of E-cadherin [9]. These activities 
were inhibited in the presence of a tissue inhibitor of metalloproteinase-2 (TIMP-2), but not TIMP-1, indicating that MT1-MMP catalytic activity was necessary [9].

CD44 binds to MT1-MMP via blade I of the HPX domain [3,15]. While MT1-MMP can cleave CD44 [58] and has been implicated for constitutive shedding of CD44 from the human melanoma cell surface [59], ADAM-10, MMP-9, and a chymotrypsin-like enzyme have also been described as CD44 sheddases [59-62]. In a similar fashion, both MT1-MMP and ADAM10 have been implicated in shedding DDR1 [63-65]. ADAM10 was shown to shed DDR1 upon collagen binding [65], regulating collagen-induced signaling in epidermoid carcinoma (A431), embryonic kidney (HEK293), and triple negative breast cancer (HC1806) cells. For these cell lines, shedding was insensitive to TIMP-2 or MT1-MMP knockdown [63,65], and thus MT1-MMP was not involved. In contrast, constitutive MT1-MMP-mediated DDR1 shedding was found to regulate collagen-induced signaling when DDR1 and MT1-MMP were co-expressed in COS1 cells, whereas MT1-MMP was suggested to be one of several DDR1 sheddases and regulators in HC1806 breast cancer cells [64].

MT1-MMP sheds protein-tyrosine kinase-7 (PTK7), a component of the Wnt/planar cell polarity pathway [66]. Shedding of PTK7 promoted tumor cell invasion [66]. MT1-MMP sheds mucin 16 (MUC16)/cancer antigen 125 (CA-125) from the surface of ovarian cancer cells [67]. This shedding reduces cell adhesion to mesothelial cells and may promote integrin-mediated adhesion and subsequent invasion [67]. MT1-MMP sheds extracellular matrix metalloproteinase inducer (EMMPRIN), where the released $22 \mathrm{kDa}$ fragment may subsequently regulate MMP expression [68]. MT1-MMP hydrolysis of apolipoprotein E abrogates the suppression of cell proliferation [69].

MT1-MMP releases fibronectin from the cell surface [22]. MT1-MMP knockout mice have arrested tendon development [70]. Collagenolysis by MT1-MMP was not essential for tendon development, but MT1-MMP processing of fibronectin was, resulting in the release of fibrils from fibripositors [70]. MT1-MMP sheds death receptor-6 [22] and heparin-binding epidermal growth factor [71], in the latter case resulting in activation of the epidermal growth factor receptor. MT1-MMP sheds additional cell surface biomolecules, such as syndecan-1 [72], MHC class I chain-related molecule A (see below) [73], E-cadherin (see below) [74], low-density lipoprotein receptor-related protein 1 (LRP1/CD91) [75], mucin 1 [76], and tissue trans-glutaminase [77], and processes cytokines, chemokines, and growth factors, such as the pro-tumor necrosis factor [22]. The receptor Tyr kinase erythropoietin producing hepatocellular A2 (EphA2) is cleaved by MT1-MMP [78-80]. Cleavage at the Gly391-Leu392 bond promoted EphA2 internalization and single cell breast carcinoma invasion [78,79], while cleavage at Ser432-Tyr433 promoted ligand-independent activation of RhoG by EphA2 and epidermoid carcinoma cell migration [80].

The $30 \mathrm{kDa}$ fragment released from MT1-MMP processing of the laminin-5 $\gamma 2$ chain binds to the epidermal growth factor (EGF) receptor and stimulates cell migration [81]. It has been proposed that MT1-MMP processing of ECM components results in products binding to the $\beta 1$ integrin, activation of the integrin leading to FAK phosphorylation at Tyr397, and the protection of tumor cells from chemotherapy- or radiotherapy-induced DNA damage [82]. Alternatively, MT1-MMP processing of collagen exposes RGD motifs $[83,84]$, resulting in a shift from intact collagen binding to the $\alpha 2 \beta 1$ integrin to RGD-containing collagen fragments binding to the $\alpha v \beta 3$ integrin [83]. This shift results in FAK phosphorylation at Tyr576 and Tyr577, the activation of ERK, and the promotion of cell migration [83]. ECM processing by MT1-MMP also promotes focal adhesion turnover, which facilitates migration [85]. MT1-MMP processing of type I collagen correlates with the repression of mature let-7, a tumor suppressive family of microRNAs, in pancreatic cancer [86].

Pancreatic ductal adenocarcinoma (PDAC) tumors increase the expression of MT1-MMP and TGF- $\beta 1$ [87]. MT1-MMP processing of TGF- $\beta$ results in the activation of this growth factor, increased collagen production by PDAC stellate cells, and hence an increased fibrotic microenvironment ("desmoplastic reaction") [88]. Blocking the MT1-MMP function in 3D collagen gels sensitizes PDAC cells to gemcitabine $[87,89]$. This has been postulated as being due to products of MT1-MMP activity activating integrins and/or growth factor receptors and subsequent signaling enhancing ERK1/2 
phosphorylation $[87,89]$. Over time, the increased production of collagen and TGF- $\beta$ induces Smad $3 / 4$ and subsequently Snail, a regulator of EMT, in PDAC cells $[87,90]$. Snail then increases the expression of MT1-MMP, resulting in MT1-MMP-mediated PDAC cell invasion of collagen [90]. Snail1 increases the expression of MT1-MMP and breast carcinoma basement membrane invasion [91].

MT1-MMP extracellular activity can also inhibit cancer progression. MT1-MMP shedding of endoglin (CD105) results in the release of sEndoglin, which inhibits angiogenesis [92]. MT1-MMP sheds lymphatic vessel endothelial hyaluronan receptor-1 (LYVE-1) on lymphatic endothelial cells, inhibiting lymphangiogenesis and possibly lymphatic metastasis [93].

MT1-MMP is secreted in exosomes (extracellular vesicles) and is enzymatically active [94,95]. In rat models, pancreatic cancer-derived exosomes possess MT1-MMP, which then contributes to pre-metastatic niche formation [96].

MT1-MMP is glycosylated in the linker region between the CAT and HPX domains (Figure 1). Glycosylation can occur at Thr291, Thr299, Thr300, and Ser301, and Ser304 [97]. MT1-MMP may be differentially glycosylated in cancer cell lines [97-99]. Glycosylation does not impact zymogen activation, but does impact the interaction of MT1-MMP with TIMP-2 and the formation of the MT1-MMP•TIMP-2•proMMP-2 complex needed for proMMP-2 activation [98]. One report indicated that pericellular collagenolysis is not impacted by glycosylation [98], while another report came to the opposite conclusion [99]. It has been hypothesized that glycosylation may regulate TIMP-2-mediated endocytosis of MT1-MMP [98] and/or the conformation of MT1-MMP [99].

\subsubsection{The Role of MT1-MMP in Immunosuppression}

MT1-MMP sheds tumor cell MHC class I chain-related molecule A (MICA) [73]. Engagement of MICA to NKG2D stimulates natural killer (NK) and T-cell antitumor activity [73]. Protection of MICA stimulated antitumor immunity and reduced metastasis in a humanized melanoma mouse model [100].

An MT1-MMP antibody, Fab 3369, reduced lung metastases following treatment of an MDA-MB-231 triple-negative breast cancer xenograft mouse model [101]. Examination of tumor cryosections revealed an increased density of iNOS+ cells (a marker of anti-tumor M1 tumor-associated macrophages) and Granzyme B+ cells [101]. The MT1-MMP antibody DX-2400, when applied in the 4T1 triple-negative breast cancer mouse model, inhibited tumor growth, shifted macrophages towards the antitumor M1-like phenotype, and reduced activated TGF $\beta$ (an immunosuppressive cytokine) [102]. TGF- $\beta$ has been implicated as a signaling molecule produced by tumor cells that activates stromal cells [103] and, along with cancer ECM dysregulation, is associated with checkpoint (PD-1) blockade failure [104].

\subsection{Intracellular Catalytic Activities}

Subcellular mapping of the human proteome revealed that MT1-MMP is mainly localized to the cytosol and additionally to the intermediate filaments [105](http://www.proteinatlas.org/ ENSG00000157227-MMP14/cell). MT1-MMP is trafficked along the tubulin cytoskeleton [106]. MT1-MMP is present in Rab-4-positive vesicles in the pericentrosomal compartment [107]. MT1-MMP exhibits several intracellular activities, including the cleavage of pericentrin (an integral centrosomal protein that coordinates the mitotic spindle) [106], the centrosomal breast cancer type 2 susceptibility gene (BRCA2) [108], metabolic enzymes (see below), and the cytoskeletal proteins ezrin and moesin [109].

Deletion of MT1-MMP was found to correlate with changes in several metabolic pathways, where 142 proteins were significantly higher and 325 proteins significantly lower in MT1-MMP knockout tissue compared with wild-type tissue [24]. Glycogen synthase decreased while glycogen phosphorylase increased in MT1-MMP knockout tissue, resulting in decreased glycogenesis and increased glycogenolysis [24]. MT1-MMP intracellular substrates identified from cell-based proteomics include enolase- $\beta$, enolase- $\gamma$, fructose-bisphosphate aldolase A (ALDOA), glyceraldehyde 3-phosphate 
dehydrogenase (GAPDH), and phosphoglycerate phosphokinase 1 (PGK1) [109]. The above proteomic analysis revealed that ALDOA was significantly increased in MT1-MMP KO mice, suggesting that it is an in vivo substrate for MT1-MMP [24]. If MT1-MMP cleaved the above enzymes in tumor cells, glucose metabolism would be stopped at the fructose-1,6-bisphosphate (F1,6BP) stage (Figure 2). One result would be that the use of glucose shifted to the pentose phosphate pathway, hexosamine synthesis pathway, and glycogenesis [110]. A second, and perhaps more significant, result, would be enhanced Ras activation, as F1,6BP can activate Ras by acting through Cdc25 (Figure 2) [111]. The F1,6BP/Ras relationship establishes a link between glycolysis and cell proliferation [111]. Thus, MT1-MMP intracellular activity could further enhance Ras activation (Figure 2).

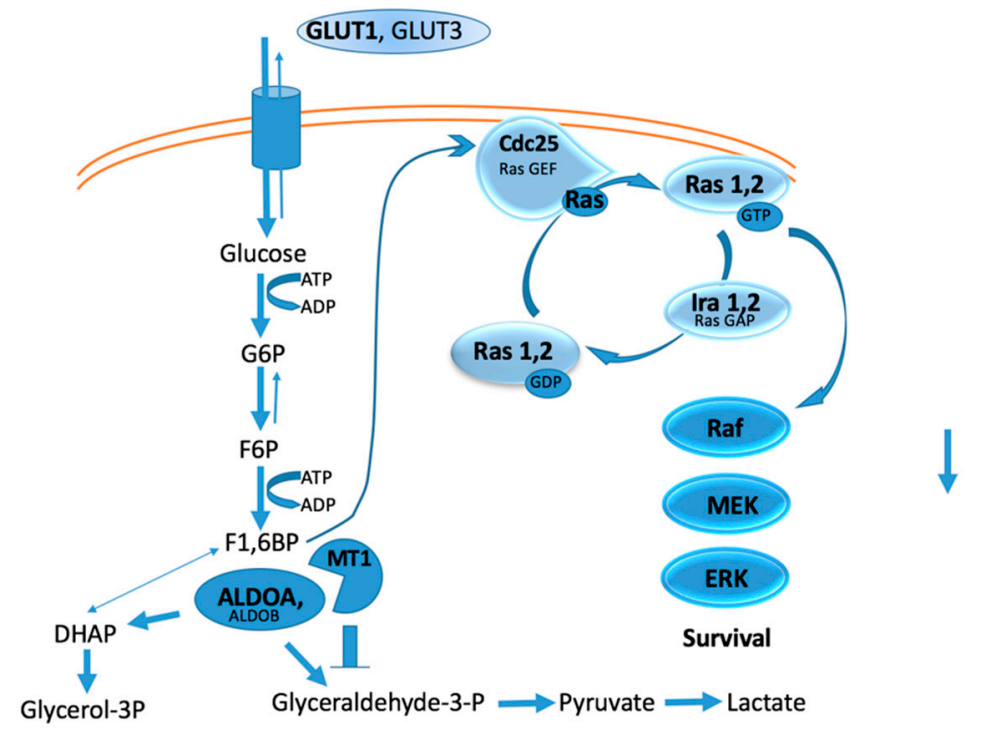

Figure 2. Hypothetical relationship between glycolysis, Ras activation, and MT1-MMP intracellular activity.

\subsection{Signaling Activities}

Posttranslational modification of the MT1-MMP CT (Figure 1) promotes tumor cell proliferation and invasion and tumor growth [112-114]. For example, LIM kinase-1 (LIMK1) phosphorylates Tyr573 in the MT1-MMP CT [115]. LIMK1 interaction with MT1-MMP modulates the catalytic activity of the enzyme [115]. Src-dependent phosphorylation of Tyr573 promotes the formation of a FAK•p130Cas $\bullet$ MT1-MMP complex, which facilitates tumor cell degradation of ECM at focal adhesion sites [116]. In contrast, Src-dependent phosphorylation of Tyr573 has been reported to impact tumor cell migration and proliferation, but not MT1-MMP catalytic activities [112,117]. Epidermal growth factor-induced phosphorylation of Tyr573 results in the internalization of MT1-MMP and expansive ovarian carcinoma cell growth [118]. Phosphorylation at Tyr573 was found to be a prerequisite for ubiquitination [119]. Mono-ubiquitination at Lys581 in the CT was catalyzed by the E3 ubiquitin-protein ligase NEDD4 [119]. A lack of ubiquitination resulted in reduced cell surface levels of MT1-MMP and increased localization in endosomes [119].

Phosphorylation of CT Thr567 regulates MT1-MMP shedding of the $\alpha 3$ integrin ectodomain in ovarian carcinoma [113]. PKC-mediated Thr567 phosphorylation increased breast cancer cell type I collagen and Matrigel invasion and growth within a 3D collagen matrix [113]. Phosphorylation of the MT1-MMP CT Thr567 enhances ovarian cancer aggregation (spheroid formation) by minimizing MT1-MMP shedding of E-cadherin [114]. Palmitoylation of Cys574 facilitates the internalization of MT1-MMP by the clathrin-dependent pathway [120].

The MT1-MMP CT stimulated aerobic glycolysis (and ATP production) by increasing the expression of hypoxia-inducible factor $1 \alpha$ (HIF-1 $\alpha$ ) target genes [121,122]. More specifically, Factor Inhibiting HIF-1 (FIH-1) binds to the MT1-MMP CT, directing FIH-1 to interact with Mint3 and deterring FIH-1 repression 
of HIF-1 transcriptional activity $[28,122]$. Thus, under normoxia, aerobic glycolysis (the Warburg effect) occurs, accompanied by active HIF-1 [28,122]. HIF-1 increases the expression of glucose transporter 1 (GLUT1), hexokinase 2 (HK2), lactate dehydrogenase (LDHA), and monocarboxylate transporter 4 (MCT4) [110]. The overall result is more glucose coming into the cell, more conversion of glucose to pyruvate and then to lactate, and more lactate secretion from the cell [110]. Inhibiting the CT interactions of MT1-MMP decreased lactate production and tumor growth [122].

MT1-MMP stimulated melanoma motility by signaling independent of catalytic activity [123]. The Ras/Raf/ERK1/2 signaling cascade is induced upon low, physiological levels of TIMP-2 binding to MT1-MMP and promotes cell migration and tumor growth $[9,124]$. TIMP-2 also promotes signaling in the catalytically inactive mutant of MT1-MMP, and pathway induction is based on TIMP-2 binding to the HPX domain of MT1-MMP [124]. The growth of tumor xenografts expressing wild-type or catalytically inactive MT1-MMP greatly exceeded that of tumors that expressed no MT1-MMP $[9,124]$. Additional studies support the notion that cell migration may not require catalytic activity or the CT, and may be due to HPX domain interactions with cell surface binding partners [125]. The MT1-MMP $\mathrm{CT}$ is required for concanavalin-A-induced autophagy in glioblastoma cells [126]. Ultimately, by associating with cell surface ECM receptors, receptor Tyr kinases, and tetraspanins via ectodomains, and intracellular signaling proteins via the CT, MT1-MMP can remodel the ECM and promote signaling [26]. In contrast, increased COS-7 cell migration via ERK activation required catalytic activity and the CT of MT1-MMP [127].

MT1-MMP catalytic activity was required for mammary epithelial cells branching in dense but not sparse three-dimensional collagen gels [128]. In comparison, a non-proteolytic function of MT1-MMP was found to be required for branching in both dense and sparse conditions [128]. MT1-MMP directly associated with the $\beta 1$ integrin subunit through the MT1-MMP transmembrane domain and CT, and this interaction modulated the $\beta 1$ integrin-dependent signals that mediated mammary epithelial cell invasion during branching morphogenesis [128].

MT1-MMP•CD44 association leads to localization to lamellipodia [15,129]. The interaction of MT1-MMP with CD44 promotes signaling through EGFR activation to the MAPK and PI3K pathways, enhancing cell migration [3]. The cytoplasmic tails of MT1-MMP and CD44 can simultaneously bind to the FERM domain of radixin [130]. Radixin interacts with the region spanning residues 566-576 of the MT1-MMP CT [130].

Interaction of MT1-MMP cytoplasmic tail binding protein 1 (MTCBP-1) with MT1-MMP displaces the enzyme from invadopodia by disrupting the interaction of the CT Leu-Leu-Tyr region (residues 571-573) with F-actin [131]. This in turn reduces pancreatic cancer metastasis [131].

\subsection{Transcription Regulatory Activities}

MT1-MMP regulation of transcriptional programs has been demonstrated in a number of cell lines [121,132]. Overexpression of MT1-MMP increased the transcription of vascular endothelial growth factor A (VEGF-A) in MCF-7 and U251 cells and, concurrently, tumor growth, angiogenesis, and metastasis [54,133]. Transcription of VEGF-A was regulated through MT1-MMP catalytic activity and the CT, as well as Src kinase activity [132]. MT1-MMP regulated the transcription of dickkopf-related protein 3 (DKK3) in urothelial cells and Smad1 in several tumor cell lines [132]. In phorbol-12-myristate-13-acetate (PMA)-stimulated HT1080 cells, the expression of MT1-MMP modulated inflammasome gene expression [134]. The transcription of IL-33 and IL-12A was MT1-MMP-dependent [134]. MT1-MMP was found to translocate to the nucleus, where it induced the expression and activation of the phosphoinositide 3-kinase $\delta / A k t / G S K 3 \beta$ signaling cascade [135]. Induction of this cascade modulated macrophage immune responses $[135,136]$. MT1-MMP catalytic activity decreases the expression of the tumor suppressor SPRY4 in metastatic melanoma through an MMP-2/RAC1 pathway; a higher expression of SPRY4 correlated with a longer survival of melanoma patients [137]. 


\section{Overview}

The initial view of the role of MT1-MMP in cancer progression was straightforward: activation of proMMP-2 and degradation of fibrillar collagen to facilitate metastasis. The contributions of MT1-MMP to cancer progression are now viewed as far more complex based on the number of MT1-MMP substrates identified. MT1-MMP activity has a negative impact on immune responses to tumors, and intracellular MT1-MMP activity regulates cancer cell metabolic functions. MT1-MMP has a significant role in angiogenesis, whereby it can exhibit both pro-angiogenic and anti-angiogenic behaviors $[19,47,48,138-143]$. These contrasting behaviors point to the importance of the spatial and temporal expression of MT1-MMP. Active MT1-MMP has been found to be highly expressed in stromal cells of the tumor microenvironment (cancer-associated fibroblasts, macrophages, etc.) rather than the tumor epithelium in mouse models of pancreatic and breast cancer $[103,131]$. Thus, there are considerations as to how the tumor induces MT1-MMP production. The tumor microenvironment also impacts MT1-MMP activity based on the local $\mathrm{pH}$ and oxygen and nutrient content.

Several creative strategies have led to the development of highly selective MT1-MMP activity inhibitors [144-146]. Of particular interest would be approaches that avoid active site targeting of MT1-MMP, in consideration of prior failures of active site targeting MMP inhibitors in clinical trials. Numerous antibodies have been described that modulate MT1-MMP proteolytic activity by interacting with secondary binding sites (exosites) [144-146]. In a similar fashion, the compound NSC405020 [3,4-dichloro-N-(1-methylbutyl)benzamide] was found to bind to the MT1-MMP HPX domain, inhibit MT1-MMP homodimerization, and reduce tumor size significantly in mouse models [147]. Inhibitors could be designed to disrupt cell surface complexes, such as MT1-MMP association with tetraspanins, the $\alpha 2 \beta 1$ and $\alpha \mathrm{v} \beta 3$ integrins, CD44, and the ternary complex with tetraspanins and the $\alpha 3 \beta 1$ integrin. Peptide IS4 (acetyl-VMDGYPMP-NH $\mathrm{N}_{2}$ ), modeled on the region of the MT1-MMP HPX domain that binds CD44 (the outermost strand of blade I), inhibited MT1-MMP-mediated cell migration and metastasis in vivo [125]. CT interactions of MT1-MMP can be inhibited using a peptide model (7R)-CPT (RRRRRRRGRRHGTPRRLLYCQRSLLDKV), resulting in decreased tumor growth [122]. Inhibitors of signaling pathways that impact MT1-MMP function can also be utilized to modulate the enzyme. In order to impact cancer in a positive way, the successful application of these inhibitors will require a thorough consideration of mode of administration (systemic versus topical), mechanism of action (extracellular versus intracellular), cancer stage (pre-metastatic versus metastatic), and potential side effects. It is worth noting that the inhibition of MT1-MMP activity in triple-negative breast cancer mouse models improved tumor profusion and sensitized the tumor to ionizing radiation or doxorubicin treatments [82,102].

Author Contributions: Writing—original draft preparation, G.B.F.; writing—review and editing, A.M.K. and G.B.F.

Funding: MT1-MMP studies in our laboratory have been supported by the National Institutes of Health (CA098799); the James and Esther King Biomedical Research Program (8JK01); the Center for Molecular Biology \& Biotechnology at Florida Atlantic University; and the State of Florida, Executive Office of the Governor's Department of Economic Opportunity.

Conflicts of Interest: The authors declare no conflict of interest.

\section{References}

1. Sato, H.; Takino, T.; Okada, Y.; Cao, J.; Shinagawa, A.; Yamamoto, E.; Seiki, M. A matrix metalloproteinase expressed on the surface of invasive tumour cells. Nature 1994, 370, 61-65. [CrossRef]

2. Watkins, G.A.; Jones, E.F.; Shell, M.S.; VanBrocklin, H.F.; Pan, M.-H.; Hanrahan, S.M.; Feng, J.J.; He, J.; Sounni, N.E.; Dill, K.A.; et al. Development of an optimized activatable MMP-14 targeted SPECT imaging probe. Bioorg. Med. Chem. 2009, 17, 653-659. [CrossRef]

3. Zarrabi, K.; Dufour, A.; Li, J.; Kuscu, C.; Pulkoski-Gross, A.; Zhi, J.; Hu, Y.; Sampson, N.S.; Zucker, S.; Cao, J. Inhibition of matrix metalloproteinase-14 (MMP-14)-mediated cancer cell migration. J. Biol. Chem. 2011, 286, 33167-33177. [CrossRef] 
4. Shaverdashvili, K.; Wong, P.; Ma, J.; Zhang, K.; Osman, I.; Bedogni, B. MT1-MMP modulates melanoma cell dissemination and metastasis through activation of MMP2 and RAC1. Pigment Cell Melanoma Res. 2014, 27, 287-296. [CrossRef]

5. Wu, K.P.; Li, Q.; Lin, F.X.; Li, J.; Wu, L.M.; Li, W.; Yang, Q.Z. MT1-MMP is not a good prognosticator of cancer survival: Evidence from 11 studies. Tumour Biol. 2014, 35, 12489-12495. [CrossRef]

6. Szabova, L.; Chrysovergis, K.; Yamada, S.S.; Holmbeck, K. MT1-MMP is required for efficient tumor dissemination in experimental metastatic disease. Oncogene 2007, 27, 3274-3281. [CrossRef]

7. Tomari, T.; Koshikawa, N.; Uematsu, T.; Shinkawa, T.; Hoshino, D.; Egawa, N.; Isobe, T.; Seiki, M. High throughput analysis of proteins associating with a proinvasive MT1-MMP in human malignant melanoma A375 cells. Cancer Sci. 2009, 100, 1284-1290. [CrossRef]

8. Cao, J.; Chiarelli, C.; Richman, O.; Zarrabi, K.; Kozarekar, P.; Zucker, S. Membrane type 1 matrix metalloproteinase induces epithelial-to-mesenchymal transition in prostate cancer. J. Biol. Chem. 2008, 283, 6232-6240. [CrossRef]

9. Yang, C.-C.; Zhu, L.-F.; Xu, X.-H.; Ning, T.-Y.; Ye, J.-H.; Liu, L.-K. Membrane type I matrix metalloproteinase induces an epithelial to mesenchymal transition and cancer stem cell-like properties in SCC9 cells. BMC Cancer 2013, 13, 171. [CrossRef]

10. Voura, E.B.; English, J.L.; Yu, H.Y.; Ho, A.T.; Subarsky, P.; Hill, R.P.; Hojilla, C.V.; Khokha, R. Proteolysis during tumor cell extravasation in vitro: Metalloproteinase involvement across tumor cell types. PLoS ONE 2013, 8, e78413. [CrossRef]

11. Markovic, D.S.; Vinnakota, K.; Chirasani, S.; Synowitz, M.; Raguet, H.; Stock, K.; Sliwa, M.; Lehmann, S.; Kälin, R.; van Rooijen, N.; et al. Gliomas induce and exploit microglial MT1-MMP expression for tumor expansion. Proc. Natl. Acad. Sci. USA 2009, 106, 12530-12535. [CrossRef] [PubMed]

12. Hillebrand, L.E.; Wickberg, S.M.; Gomez-Auli, A.; Follo, M.; Maurer, J.; Busch, H.; Boerries, M.; Reinheckel, T. MMP14 empowers tumor-initiating breast cancer cells under hypoxic nutrient-depleted conditions. FASEB J. 2019, 33, 4124-4140. [CrossRef] [PubMed]

13. Strongin, A.Y. Proteolytic and non-proteolytic roles of membrane type-1 matrix metalloproteinase in malignancy. Biochim. Biophys. Acta 2010, 1803, 133-141. [CrossRef] [PubMed]

14. Zhang, X.; Liu, R.; Yuan, Q.; Gao, F.; Li, J.; Zhang, Y.; Zhao, Y.; Chai, Z.; Gao, L.; Gao, X. The Precise Diagnosis of Cancer Invasion/Metastasis via 2D Laser Ablation Mass Mapping of Metalloproteinase in Primary Cancer Tissue. ACS Nano 2018, 12, 11139-11151. [CrossRef]

15. Mori, H.; Tomari, T.; Koshifumi, I.; Sato, H.; Tojo, H.; Yana, I.; Seiki, M. CD44 directs membrane-type I matrix metalloproteinase to lamellipodia by associating with its hemopexin-like domain. EMBO J. 2002, 21, 3949-3959. [CrossRef]

16. Gálvez, B.G.; Matías-Román, S.; Yáñez-Mó, M.; Sánchez-Madrid, F.; Arroyo, A.G. ECM regulates MT1-MMP localization with beta1 or alphavbeta3 integrins at distinct cell compartments modulating its internalization and activity on human endothelial cells. J. Cell Biol. 2002, 159, 509-521. [CrossRef]

17. Yañez-Mó, M.; Barreiro, O.; Gonzalo, P.; Batista, A.; Megías, D.; Genís, L.; Sachs, N.; Sala-Valdés, M.; Alonso, M.A.; Montoya, M.C.; et al. MT1-MMP collagenolytic activity is regulated through association with tetraspanin CD151 in primary endothelial cells. Blood 2008, 112, 3217-3226.

18. Lafleur, M.A.; Xu, D.; Hemler, M.E. Tetraspanin proteins regulate membrane type-1 matrix metalloproteinase-dependent pericellular proteolysis. Mol. Biol. Cell 2009, 20, 2030-2040. [CrossRef]

19. Sacharidou, A.; Koh, W.; Stratman, A.N.; Mayo, A.M.; Fisher, K.E.; Davis, G.E. Endothelial lumen signaling complexes control 3D matrix-specific tubulogenesis through interdependent Cdc42- and MT1-MMP-mediated events. Blood 2010, 115, 5259-5269. [CrossRef]

20. Schröder, H.M.; Hoffman, S.; Hecker, M.; Korff, T.; Ludwig, T. The tetraspanin network modulates MT1-MMP cell surface trafficking. Int. J. Biochem. Cell Biol. 2013, 45, 1133-1144. [CrossRef]

21. Hwang, I.K.; Park, S.M.; Kim, S.Y.; Lee, S.-T. A proteomic approach to identify substrates of matrix metalloproteinase-14 in human plasma. Biochim. Biophys. Acta 2004, 1702, 79-87. [CrossRef]

22. Tam, E.M.; Morrison, C.J.; Wu, Y.I.; Stack, M.S.; Overall, C.M. Membrane protease proteomics: Isotope-coded affinity tag MS identification of undescribed MT1-matrix metalloproteinase substrates. Proc. Natl. Acad. Sci. USA 2004, 101, 6917-6922. [CrossRef] 
23. Butler, G.S.; Dean, R.A.; Tam, E.M.; Overall, C.M. Pharmacoproteomics of a metalloproteinase hydroxamate inhibitor in breast cancer cells: Dynamics of membrane type 1 matrix metalloproteinase-mediated membrane protein shedding. Mol. Cell. Biol. 2008, 28, 4896-4914. [CrossRef]

24. Mori, H.; Bhat, R.; Bruni-Cardoso, A.; Chen, E.I.; Jorgens, D.M.; Coutinho, K.; Louie, K.; Bowen, B.B.; Inman, J.L.; Tecca, V.; et al. New insight into the role of MMP14 in metabolic balance. PeerJ 2016, 4, e2142. [CrossRef]

25. Fortelny, N.; Yang, S.; Pavlidis, P.; Lange, P.F.; Overall, C.M. Proteome TopFIND 3.0 with TopFINDer and PathFINDer: Database and analysis tools for the association of protein termini to pre- and post-translational events. Nucleic Acids Res. 2015, 43, D290-D297. [CrossRef]

26. Gingras, D.; Beliveau, R. Emerging concepts in the regulation of membrane-type 1 matrix metalloproteinase activity. Biochim. Biophys. Acta 2010, 1803, 142-150. [CrossRef]

27. Pahwa, S.; Stawikowski, M.J.; Fields, G.B. Monitoring and inhibiting MT1-MMP during cancer initiation and progression. Cancers 2014, 6, 416-435. [CrossRef]

28. Turunen, S.P.; Tatti-Bugaeva, O.; Lehti, K. Membrane-type matrix metalloproteinases as diverse effectors of cancer progression. Biochim. Biophys. Acta Mol. Cell Res. 2017, 1864, 1974-1988. [CrossRef]

29. Emonard, H.P.; Remacle, A.G.; Noël, A.C.; Grimaud, J.A.; Stetler-Stevenson, W.G.; Foidart, J.M. Tumor cell surface-associated binding site for the M(r) 72,000 type IV collagenase. Cancer Res. 1992, 52, 5845-5848.

30. Tokuraku, M.; Sato, H.; Murakami, S.; Okada, Y.; Watanabe, Y.; Seiki, M. Activation of the precursor of gelatinase $\mathrm{A} / 72 \mathrm{kDa}$ type IV collagenase/MMP-2 in lung carcinomas correlates with the expression of membrane-type matrix metalloproteinase (MT-MMP) and with lymph node metastasis. Int. J. Cancer 1995, 64, 355-359. [CrossRef]

31. Strongin, A.Y.; Collier, I.; Bannikov, G.; Marmer, B.L.; Grant, G.A.; Goldberg, G.I. Mechanism of cell surface activation of 72-kDa type IV collagenase. J. Biol. Chem. 1995, 270, 5331-5338. [CrossRef] [PubMed]

32. Atkinson, S.J.; Crabbe, T.; Cowell, S.; Ward, R.V.; Butler, M.J.; Sato, H.; Seiki, M.; Reynolds, J.J.; Murphy, G. Intermolecular autolytic cleavage can contribute to the activation of progelatinase A by cell membranes. J. Biol. Chem. 1995, 270, 30479-30485. [CrossRef] [PubMed]

33. Imai, K.; Ohuchi, E.; Aoki, T.; Nomura, H.; Fujii, Y.; Sato, H.; Seiki, M.; Okada, Y. Membrane-type matrix metalloproteinase 1 is a gelatinolytic enzyme and is secreted in a complex with tissue inhibitor of metalloproteinases 2. Cancer Res. 1996, 56, 2707-2710. [PubMed]

34. Ohuchi, E.; Imai, K.; Fujii, Y.; Sato, H.; Seiki, M.; Okada, Y. Membrane type I matrix metalloproteinase digests interstitial collagens and other extracellular matrix macromolecules. J. Biol. Chem. 1997, 272, 2446-2451. [CrossRef]

35. D'Ortho, M.P.; Will, H.; Atkinson, S.; Butler, G.; Messent, A.; Gavrilovic, J.; Smith, B.; Timpl, R.; Zardi, L.; Murphy, G. Membrane-type matrix metalloproteinases 1 and 2 exhibit broad-spectrum proteolytic capacities comparable to many matrix metalloproteinases. Eur. J. Biochem. 1997, 250, 751-757. [CrossRef] [PubMed]

36. Zhang, W.; Matrisian, L.M.; Holmbeck, K.; Vick, C.C.; Rosenthal, E.L. Fibroblast-derived MT1-MMP promotes tumor progression in vitro and in vivo. BMC Cancer 2006, 6, 52. [CrossRef]

37. Sato, H.; Takino, T. Coordinate action of membrane-type matrix metalloproteinase-1 (MT1-MMP) and MMP-2 enhances pericellular proteolysis and invasion. Cancer Sci. 2010, 101, 843-847. [CrossRef]

38. Lee, H.; Overall, C.M.; McCulloch, C.A.; Sodek, J. A critical role for the membrane-type 1 matrix metalloproteinase in collagen phagocytosis. Mol. Biol. Cell 2006, 17, 4812-4826. [CrossRef]

39. Lee, H.; Sodek, K.L.; Hwang, Q.; Brown, T.J.; Ringuette, M.; Sodek, J. Phagocytosis of collagen by fibroblasts and invasive cancer cells in mediated by MT1-MMP. Biochem. Soc. Trans. 2007, 35, 704-706. [CrossRef]

40. Sabeh, F.; Ota, I.; Holmbeck, K.; Birkedal-Hansen, H.; Soloway, P.; Balbin, M.; Lopez-Otin, C.; Shapiro, S.; Inada, M.; Krane, S.; et al. Tumor cell traffic through the extracellular matrix is controlled by the membrane-anchored collagenase MT1-MMP. J. Cell Biol. 2004, 167, 769-781. [CrossRef]

41. Amar, S.; Smith, L.; Fields, G.B. Matrix metalloproteinase collagenolysis in health and disease. Biochim. Biophys. Acta Mol. Cell Res. 2017, 1864, 1940-1951. [CrossRef]

42. Hotary, K.; Allen, E.; Punturieri, A.; Yana, I.; Weiss, S.J. Regulation of cell invasion and morphogenesis in a three-dimensional type I collagen matrix by membrane-type matrix metalloproteinases 1, 2, and 3. J. Cell Biol. 2000, 149, 1309-1323. [CrossRef]

43. Ellerbroek, S.M.; Wu, Y.I.; Overall, C.M.; Stack, M.S. Functional interplay between type I collagen and cell surface matrix metalloproteinase activity. J. Biol. Chem. 2001, 276, 24833-24842. [CrossRef] 
44. Wolf, K.; Wu, Y.I.; Liu, Y.; Geiger, J.; Tam, E.; Overall, C.; Stack, M.S.; Friedl, P. Multi-step pericellular proteolysis controls the transition from individual to collective cancer cell invasion. Nat. Cell Biol. 2007, 9, 893-904. [CrossRef]

45. Sabeh, F.; Shimizu-Hirota, R.; Weiss, S.J. Protease-dependent versus -independent cancer cell invasion programs: Three-dimensional amoeboid movement revisited. J. Cell Biol. 2009, 185, 11-19. [CrossRef]

46. Fisher, K.E.; Sacharidou, A.; Stratman, A.N.; Mayo, A.M.; Fisher, S.B.; Mahan, R.D.; Davis, M.J.; Davis, G.E. MT1-MMP- and Cdc42-dependent signaling co-regulate cell invasion and tunnel formation in 3D collagen matrices. J. Cell Sci. 2009, 122, 4558-4569. [CrossRef]

47. Chun, T.H.; Sabeh, F.; Ota, I.; Murphy, H.; McDonagh, K.T.; Holmbeck, K.; Birkedal-Hansen, H.; Allen, E.D.; Weiss, S.J. MT1-MMP-dependent neovessel formation within the confines of the three-dimensional extracellular matrix. J. Cell Biol. 2004, 167, 757-767. [CrossRef]

48. Stratman, A.N.; Saunders, W.B.; Sacharidou, A.; Koh, W.; Fisher, K.E.; Zawieja, D.C.; Davis, M.J.; Davis, G.E. Endothelial cell lumen and vascular guidance tunnel formatinon requires MT1-MMP-dependent proteolysis in 3-dimensional collagen matrices. Blood 2009, 114, 237-247. [CrossRef]

49. Castro-Castro, A.; Marchesin, V.; Monteiro, P.; Lodillinsky, C.; Rossé, C.; Chavrier, P. Cellular and Molecular Mechanisms of MT1-MMP-Dependent Cancer Cell Invasion. Annu. Rev. Cell Dev. Biol. 2016, 32, 555-576. [CrossRef]

50. Ridley, A.J. Life at the Leading Edge. Cell 2011, 145, 1012-1022. [CrossRef]

51. Knäuper, V.; Will, H.; Lopez-Otin, C.; Smith, B.; Atkinson, S.J.; Stanton, H.; Hembry, R.M.; Murphy, G. Cellular mechanisms for human procollagenase-3 (MMP-13) activation: Evidence that MT1-MMP (MMP-14) and gelatinase A (MMP-2) are able to generate active enzyme. J. Biol. Chem. 1996, 271, 17124-17131. [CrossRef]

52. Buache, E.; Thai, R.; Wendling, C.; Alpy, F.; Page, A.; Chenard, M.P.; Dive, V.; Ruff, M.; Dejaegere, A.; Tomasetto, C.; et al. Functional relationship between matrix metalloproteinase-11 and matrix metalloproteinase-14. Cancer Med. 2014, 3, 1197-1210. [CrossRef]

53. Ma, J.; Tang, X.; Wong, P.; Jacobs, B.; Borden, E.C.; Bedogni, B. Noncanonical activation of Notch1 protein by membrane type 1 matrix metalloproteinase (MT1-MMP) controls melanoma cell proliferation. J. Biol. Chem. 2014, 289, 8442-8449. [CrossRef]

54. Deryugina, E.I.; Ratnikov, B.I.; Postnova, T.I.; Rozanov, D.V.; Strongin, A.Y. Processing of integrin alpha(v) subunit by membrane type 1 matrix metalloproteinase stimulates migration of breast carcinoma cells on vitronectin and enhances tyrosine phosphorylation of focal adhesion kinase. J. Biol. Chem. 2002, 277, 9749-9756. [CrossRef]

55. Karsdal, M.A.; Larsen, L.; Engsig, M.T.; Lou, H.; Ferreras, M.; Lochter, A.; Delaissé, J.M.; Foged, N.T. Matrix metalloproteinase-dependent activation of latent transforming growth factor-beta controls the conversion of osteoblasts into osteocytes by blocking osteoblast apoptosis. J. Biol. Chem. 2002, 277, 44061-44067. [CrossRef]

56. Nguyen, H.L.; Kadam, P.; Helkin, A.; Cao, K.; Wu, S.; Samara, G.J.; Zhang, Q.; Zucker, S.; Cao, J. MT1-MMP Activation of TGF- $\beta$ Signaling Enables Intercellular Activation of an Epithelial-mesenchymal Transition Program in Cancer. Curr. Cancer Drug Targets 2016, 16, 618-630. [CrossRef]

57. Tatti, O.; Vehviläinen, P.; Lehti, K.; Keski-Oja, J. MT1-MMP releases latent TGF- $\beta 1$ from endothelial cell extracellular matrix via proteolytic processing of LTBP-1. Exp. Cell Res. 2008, 314, 2501-2514. [CrossRef]

58. Kajita, M.; Itoh, Y.; Chiba, T.; Mori, H.; Okada, A.; Kinoh, H.; Seiki, M. Membrane-type 1 matrix metallproteinase cleaves CD44 and promotes cell migration. J. Cell Biol. 2001, 153, 893-904. [CrossRef]

59. Nakamura, H.; Suenaga, N.; Taniwaki, K.; Matsuki, H.; Yonezawa, K.; Fujii, M.; Okada, Y.; Seiki, M. Constitutive and induced CD44 shedding by ADAM-like proteases and membrane-type 1 matrix metalloproteinase. Cancer Res. 2004, 64, 876-882. [CrossRef]

60. Lee, M.C.; Alpaugh, M.L.; Nguyen, M.; Deato, M.; Dishakjian, L.; Barsky, S.H. Myoepithelial-specific CD44 shedding is mediated by a putative chymotrypsin-like sheddase. Biochem. Biophys. Res. Commun. 2000, 279, 116-123. [CrossRef]

61. Anderegg, U.; Eichenberg, T.; Parthaune, T.; Haiduk, C.; Saalbach, A.; Milkova, L.; Ludwig, A.; Grosche, J.; Averbeck, M.; Gebhardt, C.; et al. ADAM10 is the constitutive functional sheddase of CD44 in human melanoma cells. J. Invest. Dermatol. 2009, 129, 1471-1482. [CrossRef]

62. Chetty, C.; Vanamala, S.K.; Gondi, C.S.; Dinh, D.H.; Gujrati, M.; Rao, J.S. MMP-9 induces CD44 cleavage and CD44 mediated cell migration in glioblastoma xenograft cells. Cell Signal. 2012, 24, 549-559. [CrossRef] 
63. Slack, B.E.; Siniaia, M.S.; Blusztajn, J.K. Collagen type I selectively activates ectodomain shedding of the discoidin domain receptor 1: Involvement of Src tyrosine kinase. J. Cell. Biochem. 2006, 98, 672-684. [CrossRef]

64. Fu, H.L.; Sohail, A.; Valiathan, R.R.; Wasinski, B.D.; Kumarasiri, M.; Mahasenan, K.V.; Bernardo, M.M.; Tokmina-Roszyk, D.; Fields, G.B.; Mobashery, S.; et al. Shedding of discoidin domain receptor 1 by membrane-type matrix metalloproteinases. J. Biol. Chem. 2013, 288, 12114-12129. [CrossRef]

65. Shitomi, Y.; Thøgersen, I.B.; Ito, N.; Leitinger, B.; Enghild, J.J.; Itoh, Y. ADAM10 controls collagen signaling and cell migration on collagen by shedding the ectodomain of discoidin domain receptor 1 (DDR1). Mol. Biol. Cell 2015, 26, 659-673. [CrossRef]

66. Golubkov, V.S.; Chekanov, A.V.; Cieplak, P.; Aleshin, A.E.; Chernov, A.V.; Zhu, W.; Radichev, I.A.; Zhang, D.; Dong, P.D.; Strongin, A.Y. The Wnt/planar cell polarity protein-tyrosine kinase-7 (PTK7) is a highly efficient proteolytic target of membrane type-1 matrix metalloproteinase: Implications in cancer and embryogenesis. J. Biol. Chem. 2010, 285, 35740-35749. [CrossRef]

67. Bruney, L.; Conley, K.C.; Moss, N.M.; Liu, Y.; Stack, M.S. Membrane-type I matrix metalloproteinasedependent ectodomain shedding of mucin16/ CA-125 on ovarian cancer cells modulates adhesion and invasion of peritoneal mesothelium. Biol. Chem. 2014, 395, 1221-1231. [CrossRef]

68. Egawa, N.; Koshikawa, N.; Tomari, T.; Nabeshima, K.; Isobe, T.; Seiki, M. Membrane type 1 matrix metalloproteinase (MT1-MMP/MMP-14) cleaves and releases a 22-kDa extracellular matrix metalloproteinase inducer (EMMPRIN) fragment from tumor cells. J. Biol. Chem. 2006, 281, 37576-37585. [CrossRef]

69. Aoki, T.; Sato, D.; Li, Y.; Takino, T.; Miyamori, H.; Sato, H. Cleavage of apolipoprotein E by membrane-type matrix metalloproteinase-1 abrogates suppression of cell proliferation. J. Biochem. 2005, 137, 95-99. [CrossRef]

70. Taylor, S.H.; Yeung, C.Y.; Kalson, N.S.; Lu, Y.; Zigrino, P.; Starborg, T.; Warwood, S.; Holmes, D.F.; Canty-Laird, E.G.; Mauch, C.; et al. Matrix metalloproteinase 14 is required for fibrous tissue expansion. eLIFE 2015, 4, e09345. [CrossRef]

71. Overland, A.C.; Insel, P.A. Heterotrimeric G proteins directly regulate MMP14/membrane type-1 matrix metalloprotease: A novel mechanism for GPCR-EGFR transactivation. J. Biol. Chem. 2015, 290, 9941-9947. [CrossRef]

72. Endo, K.; Takino, T.; Miyamori, H.; Kinsen, H.; Yoshizaki, T.; Furukawa, M.; Sato, H. Cleavage of syndecan-1 by membrane type matrix metalloproteinase-1 stimulates cell migration. J. Biol. Chem. 2003, 278, 40764-40770. [CrossRef]

73. Liu, G.; Atteridge, C.L.; Wang, X.; Lundgren, A.D.; Wu, J.D. The membrane type matrix metalloproteinase MMP14 mediates constitutive shedding of MHC class I chain-related molecule A independent of A disintegrin and metalloproteinases. J. Immunol. 2010, 184, 3346-3350. [CrossRef]

74. Covington, M.D.; Burghardt, R.C.; Parrish, A.R. Ischemia-induced cleavage of cadherins in NRK cells requires MT1-MMP (MMP-14). Am. J. Physiol. Renal Physiol. 2006, 290, F43-F51. [CrossRef]

75. Rozanov, D.V.; Hahn-Dantona, E.; Strickland, D.K.; Strongin, A.Y. The low density lipoprotein receptor-related protein LRP is regulated by membrane type-1 matrix metalloproteinase (MT1-MMP) proteolysis in malignant cells. J. Biol. Chem. 2004, 279, 4260-4268. [CrossRef]

76. Thathiah, A.; Carson, D.D. MT1-MMP mediates MUC1 shedding independent of TACE/ADAM17. Biochem. J. 2004, 382, 363-373. [CrossRef]

77. Belkin, A.M.; Akimov, S.S.; Zaritskaya, L.S.; Ratnikov, B.I.; Deryugina, E.I.; Strongin, A.Y. Matrix-dependent proteolysis of surface transglutaminase by membrane-type metalloproteinase regulates cancer cell adhesion and locomotion. J. Biol. Chem. 2001, 276, 18415-18422. [CrossRef]

78. Sugiyama, N.; Gucciardo, E.; Tatti, O.; Varjosalo, M.; Hyytiäinen, M.; Gstaiger, M.; Lehti, K. EphA2 cleavage by MT1-MMP triggers single cancer cell invasion via homotypic cell repulsion. J. Cell Biol. 2013, 201, 467-484. [CrossRef]

79. Sugiyama, N.; Gucciardo, E.; Lehti, K. EphA2 bears plasticity to tumor invasion. Cell Cycle 2013, 12, $2927-2928$. [CrossRef]

80. Koshikawa, N.; Hoshino, D.; Taniguchi, H.; Minegishi, T.; Tomari, T.; Nam, S.O.; Aoki, M.; Sueta, T.; Nakagawa, T.; Miyamoto, S.; et al. Proteolysis of EphA2 Converts It from a Tumor Suppressor to an Oncoprotein. Cancer Res. 2015, 75, 3327-3339. [CrossRef] 
81. Koshikawa, N.; Minegishi, T.; Sharabi, A.; Quaranta, V.; Seiki, M. Membrane-type matrix metalloproteinase-1 (MT1-MMP) is a processing enzyme for human laminin gamma 2 chain. J. Biol. Chem. 2005, 280, 88-93. [CrossRef] [PubMed]

82. Thakur, V.; Zhang, K.; Savadelis, A.; Zmina, P.; Aguila, B.; Welford, S.M.; Abdul-Karim, F.; Bonk, K.W.; Keri, R.A.; Bedogni, B. The membrane tethered matrix metalloproteinase MT1-MMP triggers an outside-in DNA damage response that impacts chemo- and radiotherapy responses of breast cancer. Cancer Lett. 2019, 443, 115-124. [CrossRef]

83. Takino, T.; Tsuge, H.; Ozawa, T.; Sato, H. MT1-MMP promotes cell growth and ERK activation through c-Src and paxillin in three-dimensional collagen matrix. Biochem. Biophys. Res. Commun. 2010, 396, 1042-1047. [CrossRef] [PubMed]

84. Birukawa, N.K.; Murase, K.; Sato, Y.; Kosaka, A.; Yoneda, A.; Nishita, H.; Fujita, R.; Nishimura, M.; Ninomiya, T.; Kajiwara, K.; et al. Activated hepatic stellate cells are dependent on self-collagen, cleaved by membrane type 1 matrix metalloproteinase for their growth. J. Biol. Chem. 2014, 289, 20209-20221. [CrossRef] [PubMed]

85. Takino, T.; Watanabe, Y.; Matsui, M.; Miyamori, H.; Kudo, T.; Seiki, M.; Sato, H. Membrane-type 1 matrix metalloproteinase modulates focal adhesion stability and cell migration. Exp. Cell Res. 2006, 312, 1381-1389. [CrossRef]

86. Dangi-Garimella, S.; Strouch, M.J.; Grippo, P.J.; Bentrem, D.J.; Munshi, H.G. Collagen regulation of let-7 in pancreatic cancer involves TGF- $\beta 1$-mediated membrane type 1-matrix metalloproteinase expression. Oncogene 2011, 30, 1002-1008. [CrossRef] [PubMed]

87. Shields, M.A.; Dangi-Garimella, S.; Redig, A.J.; Munshi, H.G. Biochemical role of the collagen-rich tumour microenvironment in pancreatic cancer progression. Biochem. J. 2012, 441, 541-552. [CrossRef]

88. Krantz, S.B.; Shields, M.A.; Dangi-Garimella, S.; Cheon, E.C.; Barron, M.R.; Hwang, R.F.; Rao, M.S.; Grippo, P.J.; Bentrem, D.J.; Munshi, H.G. MT1-MMP cooperates with Kras(G12D) to promote pancreatic fibrosis through increased TGF- $\beta$ signaling. Mol. Cancer Res. 2011, 9, 1294-1304. [CrossRef]

89. Dangi-Garimella, S.; Krantz, S.B.; Barron, M.R.; Shields, M.A.; Heiferman, M.J.; Grippo, P.J.; Bentrem, D.J.; Munshi, H.G. Three-dimensional collagen I promotes gemcitabine resistance in pancreatic cancer through MT1-MMP-mediated expression of HMGA2. Cancer Res. 2011, 71, 1019-1028. [CrossRef]

90. Shields, M.A.; Dangi-Garimella, S.; Krantz, S.B.; Bentrem, D.J.; Munshi, H.G. Pancreatic cancer cells respond to type I collagen by inducing snail expression to promote membrane type 1 matrix metalloproteinase-dependent collagen invasion. J. Biol. Chem. 2011, 286, 10495-10504. [CrossRef]

91. Ota, I.; Li, X.-Y.; Hu, Y.; Weiss, S.J. Induction of a MT1-MMP and MT2-MMP-dependent basement membrane transmigration program in cancer cells by Snail1. Proc. Natl. Acad. Sci. USA 2009, 106, 20318-20323. [CrossRef]

92. Hawinkels, L.J.A.C.; Kuiper, P.; Wiercinska, E.; Verspaget, H.W.; Liu, Z.; Pardali, E.; Sier, C.F.; ten Dijke, P. Matrix metalloproteinase-14 (MT1-MMP)-mediated endoglin shedding inhibits tumor angiogenesis. Cancer Res. 2010, 70, 4141-4150. [CrossRef]

93. Wong, H.L.X.; Jin, G.; Cao, R.; Zhang, S.; Cao, Y.; Zhou, Z. MT1-MMP sheds LYVE-1 on lymphatic endothelial cells and suppresses VEGF-C production to inhibit lymphangiogenesis. Nat. Commun. 2016, 7, 10824. [CrossRef]

94. Hakulinen, J.; Sankkila, L.; Sugiyama, N.; Lehti, K.; Keski-Oja, J. Secretion of active membrane type 1 matrix metalloproteinase (MMP-14) into extracellular space in microvesicular exosomes. J. Cell. Biochem. 2008, 105, 1211-1218. [CrossRef]

95. Sanderson, R.D.; Bandari, S.K.; Vlodavsky, I. Proteases and glycosidases on the surface of exosomes: Newly discovered mechanisms for extracellular remodeling. Matrix Biol. 2019, 75-76, 160-169. [CrossRef]

96. Shimoda, M.; Khokha, R. Metalloproteinases in extracellular vesicles. Biochim. Biophys. Acta Mol. Cell Res. 2017, 1864, 1989-2000. [CrossRef]

97. Shuo, T.; Koshikawa, N.; Hoshino, D.; Minegishi, T.; Ao-Kondo, H.; Oyama, M.; Sekiya, S.; Iwamoto, S.; Tanaka, K.; Seiki, M. Detection of the heterogeneous O-glycosylation profile of MT1-MMP expressed in cancer cells by a simple MALDI-MS method. PLoS One 2012, 7, e43751. [CrossRef]

98. Wu, Y.I.; Munshi, H.G.; Sen, R.; Snipas, S.J.; Salvesen, G.S.; Fridman, R.; Stack, M.S. Glycosylation broadens the substrate profile of membrane type 1-matrix metalloproteinase. J. Biol. Chem. 2004, 279, 8278-8289. [CrossRef] 
99. Nguyen, A.T.; Chia, J.; Ros, M.; Hui, K.M.; Saltel, F.; Bard, F. Organelle Specific O-Glycosylation Drives MMP14 Activation, Tumor Growth, and Metastasis. Cancer Cell 2017, 32, 639-653. [CrossRef]

100. Ferrari de Andrade, L.; Tay, R.E.; Pan, D.; Luoma, A.M.; Ito, Y.; Badrinath, S.; Tsoucas, D.; Franz, B.; May, K.F., Jr.; Harvey, C.J.; et al. Antibody-mediated inhibition of MICA and MICB shedding promotes NK cell-driven tumor immunity. Science 2018, 359, 1537-1542. [CrossRef]

101. Ling, B.; Watt, K.; Banerjee, S.; Newsted, D.; Truesdell, P.; Adams, J.; Sidhu, S.S.; Craig, A.W. A novel immunotherapy targeting MMP-14 limits hypoxia, immune suppression and metastasis in triple-negative breast cancer models. Oncotarget 2017, 8, 58372-58385. [CrossRef]

102. Ager, E.I.; Kozin, S.V.; Kirkpatrick, N.D.; Seano, G.; Kodack, D.P.; Askoxylakis, V.; Huang, Y.; Goel, S.; Snuderl, M.; Muzikansky, A.; et al. Blockade of MMP14 activity in murine breast carcinomas: Implications for macrophages, vessels, and radiotherapy. J. Natl. Cancer Inst. 2015, 107, djv017. [CrossRef]

103. Amara, N.; Tholen, M.; Bogyo, M. Chemical Tools for Selective Activity Profiling of Endogenously Expressed MMP-14 in Multicellular Models. ACS Chem. Biol. 2018, 13, 2645-2654. [CrossRef]

104. Chakravarthy, A.; Khan, L.; Bensler, N.P.; Bose, P.; De Carvalho, D.D. TGF- $\beta$-associated extracellular matrix genes link cancer-associated fibroblasts to immune evasion and immunotherapy failure. Nat. Commun. 2018, 9, 4692. [CrossRef]

105. Thul, P.J.; Åkesson, L.; Wiking, M.; Mahdessian, D.; Geladaki, A.; Ait Blal, H.; Alm, T.; Asplund, A.; Björk, L.; Breckels, L.M.; et al. A subcellular map of the human proteome. Science 2017, 356, pii: eaal3321. [CrossRef]

106. Golubkov, V.S.; Boyd, S.; Savinov, A.Y.; Chekanov, A.V.; Osterman, A.L.; Remacle, A.; Rozanov, D.V.; Doxsey, S.J.; Strongin, A.Y. Membrane type-1 matrix metalloproteinase (MT1-MMP) exhibits an important intracellular cleavage function and causes chromosome instability. J. Biol. Chem. 2005, 280, 25079-25086. [CrossRef]

107. Golubkov, V.S.; Strongin, A.Y. Proteolysis-driven oncogenesis. Cell Cycle 2007, 6, 147-150. [CrossRef]

108. Wali, N.; Hosokawa, K.; Malik, S.; Saito, H.; Miyaguchi, K.; Imajoh-Ohmi, S.; Miki, Y.; Nakanishi, A. Centrosomal BRCA2 is a target protein of membrane type-1 matrix metalloproteinase (MT1-MMP). Biochem. Biophys. Res. Commun. 2014, 443, 1148-1154. [CrossRef]

109. Cauwe, B.; Opdenakker, G. Intracellular substrate cleavage: A novel dimension in the biochemistry, biology and pathology of matrix metalloproteinases. Crit. Rev. Biochem. Mol. Biol. 2010, 45, 351-423. [CrossRef]

110. Hay, N. Reprogramming glucose metabolism in cancer: Can it be exploited for cancer therapy? Nat. Rev. Cancer 2016, 16, 635-649. [CrossRef]

111. Peeters, K.; Van Leemputte, F.; Fischer, B.; Bonini, B.M.; Quezada, H.; Tsytlonok, M.; Haesen, D.; Vanthienen, W.; Bernardes, N.; Gonzalez-Blas, C.B.; et al. Fructose-1,6-bisphosphate couples glycolytic flux to activation of Ras. Nat. Commun. 2017, 8, 922. [CrossRef]

112. Nyalendo, C.; Beaulieu, E.; Sartelet, H.; Michaud, M.; Fontaine, N.; Gingras, D.; Béliveau, R. Impaired tyrosine phosphorylation of membrane type 1-matrix metalloproteinase reduces tumor cell proliferation in three-dimensional matrices and abrogates tumor growth in mice. Carcinogenesis 2008, 29, 1655-1664. [CrossRef]

113. Moss, N.M.; Wu, Y.I.; Liu, Y.; Munshi, H.G.; Stack, M.S. Modulation of the membrane type 1 matrix metalloproteinase cytoplasmic tail enhances tumor cell invasion and proliferation in three-dimensional collagen matrices. J. Biol. Chem. 2009, 284, 19791-19799. [CrossRef]

114. Yang, J.; Kasberg, W.C.; Celo, A.; Liang, Z.; Quispe, K.; Stack, M.S. Post-translational modification of the membrane type 1 matrix metalloproteinase (MT1-MMP) cytoplasmic tail impacts ovarian cancer multicellular aggregate dynamics. J. Biol. Chem. 2017, 292, 13111-13121. [CrossRef]

115. Lagoutte, E.; Villeneuve, C.; Lafanechère, L.; Wells, C.M.; Jones, G.E.; Chavrier, P.; Rossé, C. LIMK Regulates Tumor-Cell Invasion and Matrix Degradation Through Tyrosine Phosphorylation of MT1-MMP. Sci. Rep. 2016, 6, 24925. [CrossRef]

116. Wang, Y.; McNiven, M.A. Invasive matrix degradation at focal adhesions occurs via protease recruitment by a FAK-p130Cas complex. J. Cell Biol. 2012, 196, 375-385. [CrossRef]

117. Nyalendo, C.; Michaud, M.; Beaulieu, E.; Roghi, C.; Murphy, G.; Gingras, D.; Béliveau, R. Src-dependent phosphorylation of membrane type I matrix metalloproteinase on cytoplasmic tyrosine 573: Role in endothelial and tumor cell migration. J. Biol. Chem. 2007, 282, 15690-15699. [CrossRef] 
118. Moss, N.M.; Liu, Y.; Johnson, J.J.; Debiase, P.; Jones, J.; Hudson, L.G.; Munshi, H.G.; Stack, M.S. Epidermal growth factor receptor-mediated membrane type 1 matrix metalloproteinase endocytosis regulates the transition between invasive versus expansive growth of ovarian carcinoma cells in three-dimensional collagen. Mol. Cancer Res. 2009, 7, 809-820. [CrossRef]

119. Eisenach, P.A.; de Sampaio, P.C.; Murphy, G.; Roghi, C. Membrane type 1 matrix metalloproteinase (MT1-MMP) ubiquitination at Lys581 increases cellular invasion through type I collagen. J. Biol. Chem. 2012, 287, 11533-11545. [CrossRef]

120. Anilkumar, N.; Uekita, T.; Couchman, J.R.; Nagase, H.; Seiki, M.; Itoh, Y. Palmitoylation at Cys574 is essential for MT1-MMP to promote cell migration. FASEB J. 2005, 19, 1326-1328. [CrossRef]

121. Koziol, A.; Martín-Alonso, M.; Clemente, C.; Gonzalo, P.; Arroyo, A.G. Site-specific cellular functions of MT1-MMP. Eur. J. Cell Biol. 2012, 91, 889-895. [CrossRef]

122. Sakamoto, T.; Niiya, D.; Seiki, M. Targeting the Warburg effect that arises in tumor cells expressing membrane type-1 matrix metalloproteinase. J. Biol. Chem. 2011, 286, 14691-14704. [CrossRef]

123. Iida, J.; Wilhelmson, K.L.; Price, M.A.; Wilson, C.M.; Pei, D.; Furcht, L.T.; McCarthy, J.B. Membrane type-1 matrix metalloproteinase promotes human melanoma invasion and growth. J. Invest. Dermatol. 2004, 122, 167-176. [CrossRef]

124. D'Alessio, S.; Ferrari, G.; Cinnante, K.; Scheerer, W.; Galloway, A.C.; Roses, D.F.; Rozanov, D.V.; Remacle, A.G.; Oh, E.S.; Shiryaev, S.A.; et al. Tissue inhibitor of metalloproteinases-2 binding to membrane-type 1 matrix metalloproteinase induces MAPK activation and cell growth by a non-proteolytic mechanism. J. Biol. Chem. 2008, 283, 87-99. [CrossRef]

125. Cao, J.; Kozarekar, P.; Pavlaki, M.; Chiarelli, C.; Bahou, W.F.; Zucker, S. Distinct roles for the catalytic and hemopexin domains of membrane type 1-matrix metalloproteinase in substrate degradation and cell migration. J. Biol. Chem. 2004, 279, 14129-14139. [CrossRef]

126. Pratt, J.; Roy, R.; Annabi, B. Concanavalin-A-induced autophagy biomarkers requires membrane type-1 matrix metalloproteinase intracellular signaling in glioblastoma cells. Glycobiology 2012, 22, 1245-1255. [CrossRef]

127. Gingras, D.; Bousquet-Gagnon, N.; Langlois, S.; Lachambre, M.P.; Annabi, B.; Béliveau, R. Activation of the extracellular signal-regulated protein kinase (ERK) cascade by membrane-type-1 matrix metalloproteinase (MT1-MMP). FEBS Lett. 2001, 507, 231-236. [CrossRef]

128. Mori, H.; Lo, A.T.; Inman, J.L.; Alcaraz, J.; Ghajar, C.M.; Mott, J.D.; Nelson, C.M.; Chen, C.S.; Zhang, H.; Bascom, J.L.; et al. Transmembrane/cytoplasmic, rather than catalytic, domains of Mmp14 signal to MAPK activation and mammary branching morphogenesis via binding to integrin beta1. Development 2013, 140, 343-352. [CrossRef]

129. Murphy, G.; Nagase, H. Localizing matrix metalloproteinase activities in the pericellular environment. FEBS J. 2011, 278, 2-15. [CrossRef]

130. Terawaki, S.; Kitano, K.; Aoyama, M.; Mori, T.; Hakoshima, T. MT1-MMP recognition by ERM proteins and its implication in CD44 shedding. Genes Cells 2015, 20, 847-859. [CrossRef]

131. Qiang, L.; Cao, H.; Chen, J.; Weller, S.G.; Krueger, E.W.; Zhang, L.; Razidlo, G.L.; McNiven, M.A. Pancreatic tumor cell metastasis is restricted by MT1-MMP binding protein MTCBP-1. J. Cell Biol. 2019, 218, 317-332. [CrossRef]

132. Eisenach, P.A.; Roghi, C.; Fogarasi, M.; Murphy, G.; English, W.R. MT1-MMP regulates VEGF-A expression through a complex with VEGFR-2 and Src. J. Cell Sci. 2010, 123, 4182-4193. [CrossRef]

133. Sounni, N.E.; Roghi, C.; Chabottaux, V.; Janssen, M.; Munaut, C.; Maquoi, E.; Galvez, B.G.; Gilles, C.; Frankenne, F.; Murphy, G.; et al. Up-regulation of vascular endothelial growth factor-A by active membrane-type 1 matrix metalloproteinase through activation of Src-tyrosine kinases. J. Biol. Chem. 2004, 279, 13564-13574. [CrossRef]

134. Sheehy, S.; Annabi, B. A Transcriptional Regulatory Role for the Membrane Type-1 Matrix Metalloproteinase in Carcinogen-Induced Inflammasome Gene Expression. Gene Regul. Syst. Bio. 2017, 11, 1-13. [CrossRef]

135. Shimizu-Hirota, R.; Xiong, W.; Baxter, B.T.; Kunkel, S.L.; Maillard, I.; Chen, X.W.; Sabeh, F.; Liu, R.; Li, X.Y.; Weiss, S.J. MT1-MMP regulates the PI3K $\delta \cdot M i-2 / N u R D-d e p e n d e n t$ control of macrophage immune function. Genes Dev. 2012, 26, 395-413. [CrossRef]

136. Thakur, V.; Bedogni, B. The membrane tethered matrix metalloproteinase MT1-MMP at the forefront of melanoma cell invasion and metastasis. Pharmacol. Res. 2016, 111, 17-22. [CrossRef] 
137. Shaverdashvili, K.; Zhang, K.; Osman, I.; Honda, K.; Jobava, R.; Bedogni, B. MT1-MMP dependent repression of the tumor suppressor SPRY4 contributes to MT1-MMP driven melanoma cell motility. Oncotarget 2015, 6, 33512-33522. [CrossRef]

138. Zhou, Z.; Apte, S.S.; Soininen, R.; Cao, R.; Baaklini, G.Y.; Rauser, R.W.; Wang, J.; Cao, Y.; Tryggvason, K. Impaired endochondral ossification and angiogenesis in mice deficient in membrane-type matrix metalloproteinase 1. Proc. Natl. Acad. Sci. USA 2000, 97, 4052-4057. [CrossRef]

139. Koike, T.; Vernon, R.B.; Hamner, M.A.; Sadoun, E.; Reed, M.J. MT1-MMP, but not secreted MMPs, influences the migration of human microvascular endothelial cells in 3-dimensional collagen gels. J. Cell. Biochem. 2002, 86, 748-758. [CrossRef]

140. Saunders, W.B.; Bohnsack, B.L.; Faske, J.B.; Anthis, N.J.; Bayless, K.J.; Hirschi, K.K.; Davis, G.E. Coregulation of vascular tube stabilization by endothelial cell TIMP-2 and pericyte TIMP-3. J. Cell Biol. 2006, 175, 179-191. [CrossRef]

141. Genís, 1.; Gálvez, B.G.; Gonzalo, P.; Arroyo, A.G. MT1-MMP: Universal or particular player in angiogenesis? Cancer Metastasis Rev. 2006, 25, 77-86. [CrossRef]

142. Onimaru, M.; Yonemitsu, Y.; Suzuki, H.; Fujii, T.; Sueishi, K. An autocrine linkage between matrix metalloproteinase-14 and Tie-2 via ectodomain shedding modulates angiopoietin-1-dependent function in endothelial cells. Arterioscler. Thromb. Vasc. Biol. 2010, 30, 818-826. [CrossRef]

143. Sounni, N.E.; Paye, A.; Host, L.; Noël, A. MT-MMPs as Regulators of Vessel Stability Associated with Angiogenesis. Front. Pharmacol. 2011, 2, 111. [CrossRef]

144. Levin, M.; Udi, Y.; Solomonov, I.; Sagi, I. Next generation matrix metalloproteinase inhibitors - Novel strategies bring new prospects. Biochim. Biophys. Acta 2017, 1864, 1927-1939. [CrossRef]

145. Santamaria, S.; de Groot, R. Monoclonal antibodies against metzincin targets. Br. J. Pharmacol. 2019, 176, 52-66. [CrossRef]

146. Fields, G.B. Mechanisms of action of novel drugs targeting angiogenesis-promoting matrix metalloproteinases. Front. Immunol. 2019. accepted for publication.

147. Remacle, A.G.; Golubkov, V.S.; Shiryaev, S.A.; Dahl, R.; Stebbins, J.L.; Chernov, A.V.; Cheltsov, A.V.; Pellecchia, M.; Strongin, A.Y. Novel MT1-MMP small-molecule inhibitors based on insights into hemopexin domain function in tumor growth. Cancer Res. 2012, 72, 2339-2349. [CrossRef] 